How to Cite

Hayati, N. M. A. M. (2019). Engineering study on oriflame cosmetic. International Journal of Engineering \& Computer

Science, 2(1), 32-36. https://doi.org/10.31295/ijecs.v2n1.70

\title{
Engineering Study on Oriflame Cosmetic
}

\author{
Ni Made Ayu Mirah Hayati \\ Institution of Science Scholar, Tabanan, Indonesia \\ Email: ayumirahhayati@gmail.com
}

\begin{abstract}
In this modern era are so many beauty products on the market ranging from legal and illegal, many also now servicing beauty clinics and doctors growing beauty with sophisticated tools. Oriflame became one of the beauty products that exist in Indonesia trying to offer products that are natural and provide business opportunities with cosmetic. Oriflamme cosmetic is one beauty product that is widely used in Indonesia because of this cosmetic can be used for all skin types especially for tropical areas such as material natural Indonesia.kosmetika from Sweden. Some ingredients of cosmetics Oriflame among blueberry, horse chestnut, yarrow, iris, palm, birch, cloudberry, apples and so forth. Oriflamme itself not only produce cosmetic to be marketed but Oriflame also provides land for business in Oriflame, so as a member of Oriflame not only able to use the product also can take advantage of the opportunity to become a career.
\end{abstract}

Keywords---beauty, business, illegal, modern, product.

\section{Introduction}

Oriflame is a cosmetics company that offers cosmetic products and high-quality natural skin care through a network of independent sellers (independent sales force), which is different from the traditional retail environment. Systems direct sales allow customers to get advice and inspiration from people they know and trust. Purchasing directly reliable and very pleasant (Al-Bader et al., 2012; Barel et al., 2014).

Being an Oriflame Sales Consultant means unlimited income and career opportunities are exceptional, personal development and a sense of belonging to a community of friendship global. An Oriflame company with characteristics spirit of "I can", the management of scattered, with a young and entrepreneurial atmosphere is high.

Oriflame Cosmetics is currently the fastest-growing cosmetics companies in the world. Oriflame has sales operations in 59 countries and is the market leader in more than 30 countries. A sales force of 1.8 million independent Sales Consultants markets a complete range of skin care, fragrances, and cosmetics high. Although quality has grown rapidly it has never lost sight of its original business concept - Natural Swedish Cosmetics sold from friend to friend (Coulter et al., 2002; Fluhr, 2014).

In this article titled Oriflame cosmetic, its talk about why choose Oriflame cosmetic, Any of Oriflame products, How to do business in Oriflame cosmetic, Oriflame cosmetic benefits of being members. Making women in Indonesia for more intelligent, not only can spend the money on shopping for cosmetics but also how to take advantage of a business opportunity. Here I introduce Oriflame cosmetics as one of the products that are well known in Indonesia that are safe for use on tropical climate and made of natural materials, Oriflame also provides a consultant for consultation for costumes or new members of Oriflame and business opportunities (Gurkov, 2016; Messaraa et al., 2018).

ISSN 2632-945X

Received Jan 20, 2019 / Accepted Jun 18, 2019 / Published Jul 05, 2019 


\section{Discussion}

\section{Oriflame as a selection of products that are preferred in Indonesia}

In Indonesia alone, Oriflame was founded in 1986 and has triumphed in Indonesia for 21 years. Oriflame has 12 branches and thousands of consultants are widespread throughout Indonesia. For now, Indonesia is a cosmetics company Oriflame with independent sales system no.1 in Indonesia (Oh et al., 2006; Semuel et al., 2014).

ProdukOriflame committed to providing products made from high-quality natural, according to the slogan, 'Natural Swedish Cosmetics ". Oriflame products are not tested on animals, and every new active ingredient can be launched after a minimum through a thorough research in the laboratory for a minimum 5tahun Oriflame in Stockholm, Swedia. Oriflame provides a variety of products which vary according to sex, age, and various types of skin, In each catalog, contained more than 800 products sold.

In general lines Oriflame products are divided into, four major sections:

- Skin Care

- Color Cosmetics

- Body \& Hair Care

- Fragrance

And now Oriflame has launched its newest product is Nutrishake, complementary foods for health and maintaining a healthy weight.

Plan (Systems) Oriflame is a direct selling system integration and multi-level marketing that makes this system very easily duplicated and studied by everyone. With its motto, "Make Money Today Fulfill Your Dreams Tomorrow, the second combiner is so profitable method of its Consultant. By showing the catalog and make sales, you can get a direct benefit of $30 \%$ of the price member. By inviting people to join, and to guide, you have the opportunity to earn an award more. Oriflame has a career and a clear system of bonus calculations and can be learned by everyone. This means that every member has an equal opportunity to benefit from Oriflame, such as - Bonuses ranging from 30rb up to 7 billion

- Free car

- Traveling overseas for free

- self-development

Of course, this can be achieved with good cooperation between the upline and downline, in one team cooperation to help each other.

People (Network) Oriflame provides a variety of facilities and training that can be used by all members to develop. From time to time on a regular basis, Oriflame held seminars personal development that can be followed by leader-leader, who meet the qualifications. d'BC Network as a growing network in Oriflame provides a variety of online and offline support to the consultant who joined in it's always evolving. Each member is actively getting sophisticated online facilities and complete for free, such as:

The main attractive web replica, various training modules, and videos can be directly accessed by each member active in the member area the leader can monitor the development of its network in the menu provided special 18 landing page for promotion to various target markets advanced autoresponder to follow up prospects ready-made banners. Currently, the founder of d'BC Network, Nadia Meutia and Dini Shanti, is the fastest growing leader No. 2 and No. 1 in Indonesia, four of Asia and included in the global top 100.

\section{Oriflame has 950 kinds of products}

Ranging from body care, make-up, fragrances to accessories. Available for men, woman, and children. So different types for different use.Di home business world such as Oriflame, not a compulsion or whose name MUST so yes. But everything we were set. Willing to do any kind? Why not make how much? Do not want sales? Can Mau massive sales also not there is prohibited. Just the same as having our own business. We are set our targets and objectives and we specify how hard we want to achieve.

All businesses in the world there must be intention and effort. If his intention was unanimous everything must not think hard or not death. What we think about is how so that we can achieve it in accordance with a target bonus and the ability of our work. Thinking progressive not regressive. Think positive instead of a negative. Special about this 
business, for business I think no need talent, there is only a desire/willingness/ intentions and commitment to be successful and that is important to tenacity, willingness to learn great and another one to give up, Oriflame also provides training, seminars, and event to motivate and teach us how successful this business his way with the example upline-upline that has been a successful course. So do not worry make you feel do not have any talent in this business, you ga be left alone to run this business, you will always be guided and directed until you feel clever and talented in. Business Oriflame business requires relatively small capital and all facility is equipped by Oriflame, such catalogs are very cheap, starter kits are inexpensive and are also an inexpensive tester. Moreover, many free training and seminars, as well as shipping costs ready for transport at low cost. For most people in Oriflame maybe money is not the main goal to be achieved by those who join, the most concrete that can be from Oriflame, of course, body treatments, and to be able to always look pretty and fresh, and all of it can be from Oriflame, not to mention awards we get, self-actualization, can help people become successful is a pleasure.

\section{simple 7 RANGKAIAN PRODUK ORIFLAME}

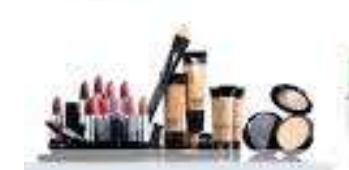

Colour Cosmetics

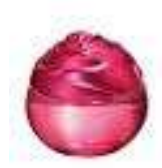

Fragrance

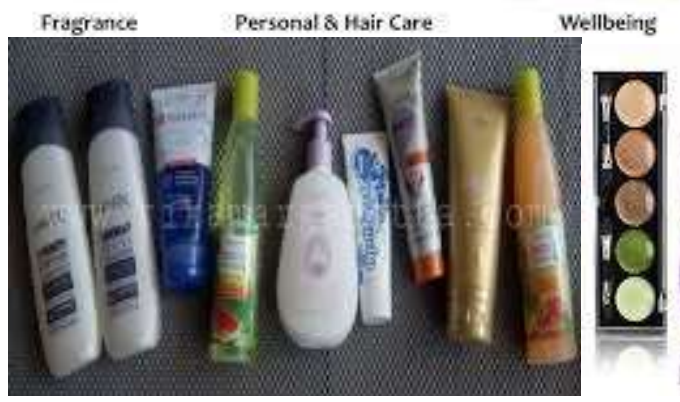

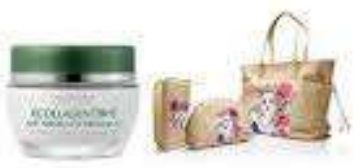

Skin Care

Accessories

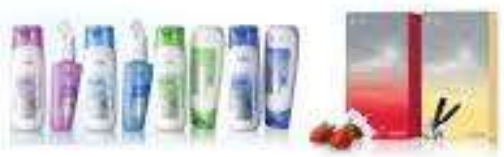

ellbeing
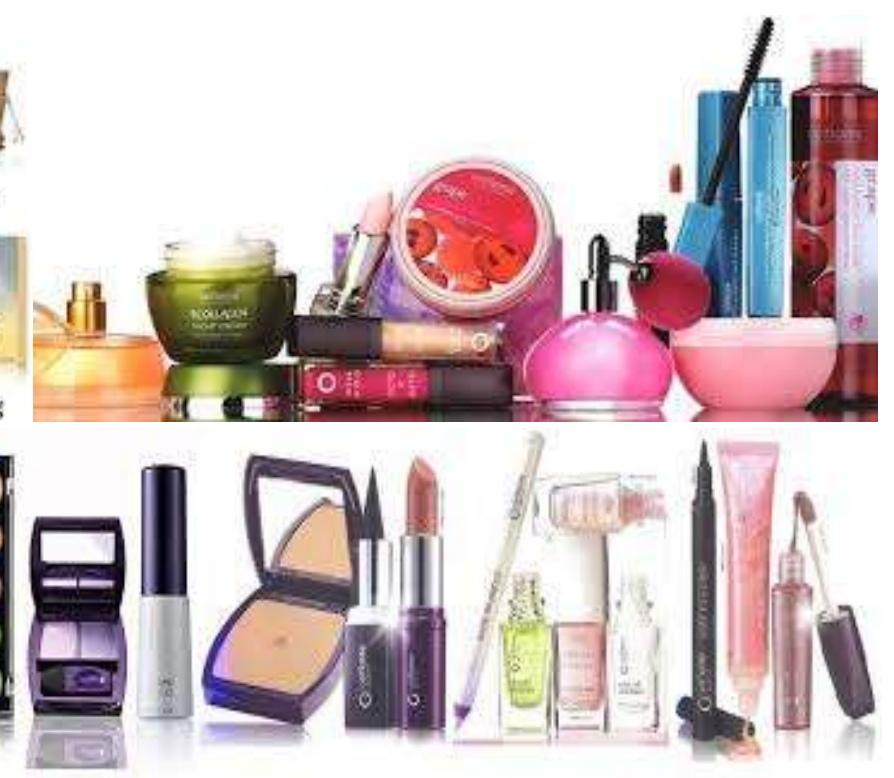

Ways of being members or doing business in Oriflame

The first way to start a business in Oriflame is you must first join Oriflame. You can join by registering yourself to Oriflame branch office in your city, can also be a way to contact Consultant Oriflame you know, or you can also join by going into Oriflame existing network. One of the Oriflame business networks that are well known and successful in Indonesia is dBC Network. dBC Network is a business network Oriflame is done online, or simply be referred to as MLM Oriflame online, If you register yourself in $\mathrm{dBC}$ Network you will receive online training or training. Then you only run Oriflame's business online is more practical. But if you enroll in a branch office Oriflame, you will be charged a registration fee of Rp.49.900. Once you register, you will get the equipment referred to as a starter kit that equipment needed to run a business Oriflame. Such equipment such as catalogs, product samples and so forth.

The second way in starting a business Oriflame is you have to follow the training that has been facilitated by Oriflame. Once you register yourself, then you only meet and follow a course training schedule that has been specified by the Oriflame. This training is useful for Oriflame business that you will live in the future. Because through this training you will be given the knowledge and skills on how to run a business Oriflame well so that you can be successful and succeed eventually. Therefore, you should not be lazing this training. Live diligently and seriously all of the training processes regarding this Oriflame.

The third way in starting a business is to run business Oriflame Oriflame. Join Oriflame you have already done. Following the training was already done. Well, the next step you just run Oriflame's business. Offer and sell Oriflame products as much as possible. The more products you sell Oriflame greater the points you will collect. And the closer you are to the car in a gift Oriflame promised to those who collect a lot of points. If you do not have the 
opportunity to win is not a problem, because the profit you can earn millions of rupiah if your performance in running a business is a good Oriflame.

\section{Personal data}

a) Full Name: Fill in the Full Name as ID

b) The full address of residence: Fill in your address "current". If you are boarding/contract contents of the address -> For the purpose of packaged goods

c) No. tel / HP: Fill your HP No.

d) E-mail address: For those of you who use Yahoo email, make sure your email is not expired (cannot be used). Many cases when registering members, turned out email is not active/forgotten password, thus inhibiting the registration process.

e) Date of Birth: Fill in your Date of Birth

f) ID number: Fill in your ID card No.

Oriflame Starter Kit (pack of new member businesses, in the form of print and e-starter kit )

a) While membership card <Member Card you will receive after you reach the rank of $6 \%$

b) Product catalog.

c) Manual consultant, in the form of guidebooks and Oriflame Policy.

d) Consultant Price list or price list member.

e) Colour Chart as Free Colors Makeup Products.

f) Skin Care Guide: Free choose skin and body care products.

g) News Letter - ah Majal 3 monthly Oriflame consultant.

\section{Some of the gains become members Oriflame}

Direct advantages of selling a product, from selling products, you earn a commission on every sale you generate by $23 \%$. The more you sell, the more you earn. If you do not like to sell, do not be discouraged, because you can still generate income of millions without becoming a seller of products, with running the business.

Advantages of Developing networking Commission (recruits), from recruiting and developing a network, you can earn extra commission appropriate career path that you earn. Career path offered Oriflame offers a variety of awards and earnings. Study career includes:

a) Level Consultant with the potential income USD - USD 500/ month

b) Managers with the potential income of 1-4 million per month

c) Level Director- Gold - Senior Gold - Sapphire with potential income between IDR 5-20 million per month

d) Diamond Level - Senior Diamond - Double Diamond with potential INCOME n 25-60 million per month

e) Executive Level - Gold Executive- Executive Sapphire - Diamond Executive with the potential income of Rp 70 to IDR 200 million per month.

f) Level President - President-Sapphire Gold President - Diamond President with potential earnings above 300 million up to billions of rupiah per month.

Excellence joins Oriflame capital only IDR 39.900, - you can get a very complete facility, among others:

a) Free websites for sale online (only applies if you join us), examples of websites that you get to see in http://www.oribizonline.net

b) Promotional tools offline (catalogs, brochures, and flyers)

c) An inter pes services throughout Indonesia

d) 14 offices c brother is ready to serve you

e) Amenities order online, email, fax and phone orders

f) Members are a web that includes online training form ebook to guide you.

g) Training and training

\section{Conclusion}

As a female wearer various beauty products we have to be smart, especially wearing the type of products that are safe and according to skin type. Oriflame here has a wide range of beauty products that are safe and adjusted to the 
tropical climate in Indonesia also has many consultants if the customer wants to consult about Oriflame products. Oriflame also provides business opportunities so women are not only the product but also to use your behavior, based as a place to make money.

The products offered are also lots ranging from skin care, makeup, perfume, household goods, etc. Oriflamme serves not only for women but also for products for men and children made from natural materials.

Join Oriflame is very easy and simple are also a lot of offers for members of Oriflame. If the intention of making Oriflame as a side business does not require substantial capital investment to the rate of loss of business Oriflame very small. For women hopefully, this info to be useful for Oriflame provide attractive business opportunities are also products on offer secure because it is made from natural ingredients, so as we women have to be smart to take advantage of existing opportunities.

\section{Acknowledgment}

Praise God Almighty for all his blessings so that this article can be arranged to complete. Do not forget I also say many thanks for the help of those who have contributed by donating both matter and mind. And my hope hopefully this article can add to their knowledge and experience for the readers, for the future can improve the shape and add the contents of the article to make it better again. Due to lack of knowledge or experience, I'm sure there are still many shortcomings in this article, therefore we welcome any suggestions and constructive criticism from readers for the perfection of this article.

\section{References}

Al-Bader, T., Byrne, A., Gillbro, J., Mitarotonda, A., Metois, A., Vial, F., ... \& Laloeuf, A. (2012). Effect of cosmetic ingredients as anticellulite agents: synergistic action of actives with in vitro and in vivo efficacy. Journal of cosmetic dermatology, 11(1), 17-26.

Barel, A. O., Paye, M., \& Maibach, H. I. (2014). Handbook of cosmetic science and technology. CRC Press.

Coulter, R. A., Feick, L. F., \& Price, L. L. (2002). Changing faces: Cosmetics opinion leadership among women in the new Hungary. European Journal of Marketing, 36(11/12), 1287-1308.

Fluhr, J. W. (2014). Practical aspects of cosmetic testing. Springer.

Gurkov, I. (2016). Oriflame CIS: The successful evolution of a regional subsidiary's mandate. Global Business and Organizational Excellence, 35(4), 44-54.

Messaraa, C., Metois, A., Walsh, M., Hurley, S., Doyle, L., Mansfield, A., ... \& Mavon, A. (2018). Wrinkle and roughness measurement by the Antera 3D and its application for evaluation of cosmetic products. Skin Research and Technology, 24(3), 359-366.

Oh, C. H., \& Rugman, A. M. (2006). Regional sales of multinationals in the world cosmetics industry. European Management Journal, 24(2-3), 163-173.

Semuel, H., \& Chandra, S. S. (2014). The analysis of corporate social responsibility implementation effects towards price fairness, trust and purchase intention at Oriflame cosmetics product in Surabaya. Procedia-Social and Behavioral Sciences, 155, 42-47. https://doi.org/10.1016/j.sbspro.2014.10.253 